\title{
German Hermeneutic and Literature Critics
}

\author{
Zhongli $\mathrm{HU}^{1}$, Weihua $\mathrm{DU}^{2 *}$ \\ ${ }^{1}$ Zhongli Hu, Guangdong University of Foreign Studies \\ ${ }^{2}$ Weihua Du, Guangdong University of Foreign Studies \\ *Corresponding author. Email: duwhgd@126.com
}

\begin{abstract}
Hermeneutics, as the "study of textual understanding", is of central importance in the various disciplines of textual studies. Friedrich Schleiermacher (1768-1834) defined it as "the art of putting oneself in possession of all the conditions of understanding". This paper tries to analyse the background of the German Hermeneutics and wants to find the theoretical frames for literature critic.
\end{abstract}

Keywords: Literature critic, German, Hermeneutic.

\section{INTRODUCTION}

The word "hermeneutics" also has its origins in ancient Greece and from there means much more than the simply interpretation of texts. Hermeneutics consists of the art of hermeneutic, which begins with the proclamation of a message. But since the message comes from another world, it must be explained and interpreted beyond the simple proclamation. For hermeneutic denotes the not only difficult but also complex task that falls to Hermes, the messenger of the gods. He must deliver messages from a world that is not only different but also of a higher order, that of the immortal gods, to mortals and humans. The relevant messages have the character of divine commands. They must therefore not only be communicated, but also translated into a language understandable by mortals and, above all, conveyed in their superior, authoritative rank [1].

The most influential tradition of hermeneutics in some places since then has developed in Christianity or has been further developed by it. For Christians, the art of interpretation proves itself in the correct interpretation of their Holy Scriptures, the Biblia sacra, the exegesis of Holy Books, or in short: The Bible. As early as the time of the Church Fathers - Origins is important - this theological hermeneutic took on its most authoritative form since then. The outstanding teacher of rhetoric, philosopher, theologian, bishop and preacher, Aurelius Augustine, the most important teacher of the Church together with Thomas Aquinas, presents it in a particularly concise and influential way.

A Christian dogmatic has the task of overcoming a fundamental tension. It exists between the history of the chosen people, the Jews, known from the now Old Testament, and the universalistic message of the New Testament. Augustine draws on the Neoplatonic notion of an ascent of the spirit. Which, in the case of biblical interpretation, leads from the literal to the moral to the spiritual sense [2].

In the transition to modern times, in the 16th century, a scholarly movement emerged, humanism, which continues to teach anew almost up to the present day. The counter-social form, which cultivates the Latin and Greek language and literature, the humanistic counter-nasal indicates the guiding goal in this self-designation. Partly in sharp contrast to the Christian ideal of life, but partly, as in the case of Erasmus of Rotterdam, in a more irenic attitude, the image of the world and of man that emerges in the classical texts of Greek and Roman antiquity is, in the broader understanding, also attributed a model function to their pictorial art and architecture. In the corresponding hermeneutics, their double meaning is revived: the relevant texts and non-textual testimonies are not only thoroughly explained, but freed from the Latin of scholasticism, which is considered barbaric. In the case of the Greek texts, one does not study the Latin translations, but the Greek original; as far as one turns to the Bible, one prefers to read it in the Hebrew original, and in doing so one opposes the actual or alleged attitudes and, beyond this in methodological terms traditional task of any hermeneutics, distortions, even the abuse by the reading tradition or church and its authorities.

Some of the most significant figures should at least be mentioned here: Friedrich Nietzsche, as a provocative interpreter of the Conditio humana, Friedrich Schleiermacher and Wilhelm Dilthey, in another way 
Ernst Cassirer and in yet another way Paul Ricoeur. They are regarded as leading theorists of a foundation of the humanities, not least Martin Heidegger, with the hermeneutics of Dasein conceived in Being and Time [3].

\section{GERMAN HERMENEUTIC}

The most influential "disciple" of Martin Heidegger, Hans-Georg Gadamer, lays a claim to universality for every hermeneutic that surpasses the mere art of understanding, through which it can, in a certain way, become the unspoken First Philosophy that used to bear a name that has meanwhile become obsolete, that of metaphysics. It is not a theory of knowledge or science that inherits fundamental philosophy here, but a theory of understanding, which for this purpose, however, is emphatically about a methodical art of interpretation, about a philological, theological or legal art of interpreting texts. According to hermeneutics, which has been declared the new basic philosophical discipline, what matters is an understanding of meaning that seeks out that "experience of truth" that pervades "all human world relations" and "transcends the sphere of control of scientific methodology" (Truth and Method, Introduction). Only such demanding hermeneutics qualifies Gadamer as "philosophical" and can expect to be recognised as a new basic discipline [4].

It is characteristic of the philosopher that in his methodological foundations Gadamer unfolds in his major work Truth and Method. Grundzüge einer philosophischen Hermeneutik (1960). The work is divided into three parts. Gadamer begins with "Uncovering the Question of Truth in the Experience of Art". Here Gadamer defends, as he points out in the introduction, "the experience of truth, which is granted to us through the work of art, against aesthetic theory [...], which allows itself to be confined by the concept of truth of the sciences". The second part: "Extension of the question of truth to understanding in the humanities", a theory of the humanities and human sciences, wants to free them from the compulsion to submit to the model of the apparently more successful natural sciences. Finally, the third part: "The ontological turn of hermeneutics on the guide of language" discusses "language as a medium of hermeneutic experience", traces the "coinage of the term 'language' by the history of thought of the Occident" and emphasises "language as experience of the world".

The higher-order world, we have seen, is highly diverse in nature. In religions, it is a matter of sacred texts, such as the Bible, also the Koran, etc. In philosophy, it arrives with the thinking of the great representatives, which is still valid today: from the pre-Socratics, before Plato and Aristotle, through countless thinkers of late antiquity, the Middle Ages and early modern times, to the main figures of modernity such as Kant and Hegel, also Schopenhauer, Nietzsche, later Husserl, Wittgenstein, Heidegger, Gadamer and many others. The situation is similar in literature, first the texts of the Greeks and Romans, later the Christians of the classics of the various linguistic areas, not least contemporary texts.

Gadamer invites us to think of the courts of justice, where judgments are not fixed social conventions, but a process of continuous refinement and modification when the old judgments encounter difficulties - the hermeneutic adjustment between the particular and the general. Validity derives from the commonality of practice and goals, not from reference to an abstract theory. Similar considerations apply to aesthetics, a field notoriously resistant to objective approaches. Works of art are not only bearers of the self-understanding and moral dimensions of the society that produces them, but also a product of the resistance that the individual circumstances of creation exert on broader truths. And these broader truths are the truths inherent in the society by which it lives, whether it is explicit or not. The natural world may be beautiful, as Kant acknowledged, but a work of art involves the play of the mental faculties of the artist in question, that is, its own kind of truth, which Kant did not acknowledge [5].

Like Heidegger, Gadamer sees language as the house of being. He also likes Wittgenstein's picture of language as a social game. It is in play (i.e., in the use of language) that we acquire an understanding of the world. And this is true in every language. It is the learning process that is important: it mimics and provides an account of human experience. And whereas Habermas sees language as a sedimented ideology, full of undiscovered corruptions and prejudices that analysis must bring to light, Gadamer sees these corruptions and prejudices as constitutive of understanding. There is no language that is free of them. Nor can we arrive at a purer form of understanding outside language. No doubt words reflect objects only imperfectly, but it is their multiple mirror surfaces on which truth becomes visible.

\section{LITERATURE CRITICS IN THE FRAME OF HERMENEUTIC}

For literary studies, insofar as the modern languages are concerned, this has entirely different consequences than for classical studies, theology, or jurisprudence. While these disciplines have at their disposal a long hermeneutic tradition which can be revised by them at any time, the discipline of literary studies dates from a time when the change in hermeneutics which Dilthey presents as the accomplishment of Schleiermacher had already occurred: the way back behind the rules, to an analysis of understand.

Research usually begins with a confusion or problem found in the research or professional literature, in education, in the media, or through experience in the field. The researcher then begins searching for more general introductory texts and particularly valuable review 
papers. She/he reads, understands, and interprets these texts and identifies other relevant texts to recognize and understand key ideas, findings, concepts, and theories and to make connections among them. In this process, understanding develops gradually as the researcher engages with the literature and conducts the research in her/his own way. Initial ideas and prior understandings are challenged, refined, and expanded in light of what is learned.

Since interpretation and understanding are central themes, we take hermeneutics as the basic philosophy and method for conducting a literature review. As a hermeneutic theory that addresses issues of textual meaning, the philosophy of hermeneutics provides a rich theoretical foundation for understanding and describing the process of literary analysis. By providing principles for understanding texts, hermeneutics provides a method for conducting literature research. Drawing from hermeneutic philosophy, we propose a hermeneutic framework for describing the process of literature research.

In the tradition of the discipline, hermeneutics has three main ideals. The first is the normative interpretation of texts of a religious, legal, or linguistic nature. Through classical interpretation we can show what God, the legislator, or the classical author really meant by the text. For Gadamer, there is no such thing as classical interpretation because texts remain open to new understandings that can release new meanings [6].

A second influential ideal of hermeneutics is the historical reconstruction of the author's intentions. Again, the text is taken as presupposed, and the interpreter's task is to recover the author's original intentions and ground them in the text. Our capacity for comprehension and the limits of our understanding coincide with our language. Being understood is what language is all about. Language, however, is something that transcends the individual and his or her history. Language and history, then, are the medium through which understanding takes place. Language and understanding are mutually dependent and are the most fundamental features of human existence in the world.

A third hermeneutic model to which Gadamer can be compared is divinatory empathy-a psychic force that supposedly bridges the story or nation between author and interpreter, allowing the interpreter to reproduce and reenact the author's creation in an understanding of peace and goodness through psychic attunement.

Eus shares Gadamer's conviction of the active role of the reader and emphasizes even more forcefully that interpretation is not merely a reproduction but a productive and creative activity. This is the common ground of their "hermeneutic aesthetics." Reception theory is not limited to examining the reader's response to a text, but insists on a genuine interaction between text and reader that reveals the "potential" of a literary work that can lead to a gradual historical unfolding of the text's inherent levels of meaning.

Gadamer directly inherits the above ontological (existential) thinking of Heidegger's hermeneutics (existential) thinking that understanding is not something that the reader (the interpreter, the subject) does through some specific (e.g., linguistic, psychological) method that is external to him. Through some specific (e.g. linguistic, psychological) method that lies externally to his belief, the reader (interpreter, subject) seeks and interprets (recognises) all texts (objects) and their author's original meaning through some specific (e.g. linguistic, psychological) method.

It is the way of being of the here (man) itself. In his Truth and Method. Heidegger's analysis of the temporality of the human here (Dasein) has been convincingly developed.

Heidegger's analysis of the temporality of the human Dasein has convincingly shown that understanding does not belong to the subject's way of acting, but to the being of this being itself.

Heidegger's analysis of the temporality of the human being (Dasein) has convincingly shown that understanding is not the way the subject acts, but the way the being itself exists.

It signifies the radical mobility of the here and now. This movement constitutes the finitude and historicity of the present, and therefore the whole of its experience of the world. It is neither arbitrary nor one-sided

It is the nature of things that makes the movement of understanding all-embracing and omnipresent. In this way, the traditional epistemological and methodological concept of 'understanding' is deepened into the basic prescription of a human (here) category.

Gadamer thus reverses the traditional conception of the subject and object of 'understanding' as prior, fixed and dichotomous. The traditional notion of the subject and object of understanding as fixed and dichotomous is thus reversed, and the subject and object of understanding are constructed simultaneously in the activity of understanding. In this generative sense, the

On the one hand, this (the person) as subject is constructed, produced and presented in the activity of understanding; on the other hand, the subject is constructed, produced and presented in the activity of understanding.

On the other hand, the text (in the broad sense) as an object of comprehension is not merely a fixed text or a finished product (a text) made up of language outside the person. The text as an object of comprehension is not just a fixed or unchanging text or product outside the person, but is also from a hermeneutic standpoint, the text is only 
a half-finished product, but it is also constructed and produced during the activity of comprehension.

The text is only a semi-finished product, a stage in the process of comprehension. In this way, the meaning of the text is not external to the person (here) in the sense of some object of awareness, and even more so, it is not just a fixed meaning given by the author of the text. But in the process of comprehension, i.e. in the dual construction of the text and the person (the person), it is generated in the process of understanding, i.e. the construction of both the text and the person. It is this fundamental movement that determines understanding.

Like Jauss, Wolfgang Iser also elaborates the important role of the reader as a dimension of reception. The important role of the reader as a receptive dimension is clearly illustrated by the fact that the text is brought to life only when it is read by the reader. Each reading experience renews the meaning of the text in real time. The meaning of the text is updated in real time with each reading experience. The less the meaning of a text is determined, the more deeply the reader is involved in the meaning-making process. In the analysis of texts with "evocative structures," Iser focuses on how the text acts on the reader, evoking the reader's previous reading. The text has an evocative structure. Starting with textual features, Iser first analyzes the fundamental differences between general texts and literary texts.

A literary work is a figurative expression of the world of people's lives and imaginations, expressing thoughts and feelings. The concept of "Unbestimmtheit" is used to propose the theory of the blankness of the text. The literary work contains many "unqualified" and empty spaces. The unqualified and empty spaces in this sense are the basic elements of the literary effect of the work and constitute the unique structure of the literary work. This is the so-called evocative structure of a literary text.

Jauss and Iser pioneered the theory of the aesthetics of reception, arguing that the study of literary history and literary works must focus on the reception process of the reader. This was the first time that readers were systematically included in the study of literature, establishing the active position of readers in the reading process, and thus making an important contribution to the improvement of literary theory. Aesthetics of reception is both a theory of literary texts and a theory of readers' reception. The study of the mechanisms of reader reception and text structure in Reception Aesthetics goes back first to the phenomenological focus on consciousness and the study of the structure of texts.

At the same time, hermeneutic ideas have inspired the study of the reception dimension: In the context of changing expectations, literary texts produce different meanings. Gadamer's philosophical hermeneutics establishes a dialogical relationship between the "present" reader and the "past" tradition, revealing that an important feature of understanding is the dialogical nature, i.e. the dialogue between the knowing subject and the text. This is the dialogue between the subject of knowledge and the text. This dialogical communication is fully inherited and developed in the aesthetics of reception.

Literary reading is an activity of communication between the real reader and the historical text. Reception aesthetics regards the reading of a text as an activity of communication with the reader and promotes the importance of dialogue and communication in literary reading, reflecting the interaction between text and reader, history and reality.

\section{CONCLUSIONS}

The German hermeneutics has its tradition in Greece and Rome, but the German philosophers represent this research method, from Schleiermacher to Friedrich Nietzsche, from Wilhelm Dilthey to Gadamer, there is a clear theoretical way. For literary critics, hermeneutics can be a good method. Dilthey's attitude toward comparative literature was spontaneously sympathetic. The comparative study of works of art of all times and all people must gather the material for an inductive aesthetics. Unlike Dilthey, Gadamer follows from the standpoint of radical historical facticity the model of a vertical and immediate contact with the poetic past as an individual and unrepeatable experience. This applies to all the concepts we cherish, such as aesthetic value, authorial intention, consensus, common heritage, evolution, continuity, etc.

\section{ACKNOWLEDGMENTS}

Project "German Hermeneutic Theories" of Guangdong University of Foreign Studies by Zhongli HU (2020-13) and Project of Hermeneutic Institute of Guangdong University of Foreign Studies (CSY-2019-B03).

\section{REFERENCES}

[1] E. Behler, The new hermeneutics and comparative literature, Neohelicon 1983(03).

[2] F. Schleiermacher, Hermeneutik. Nach den Handschriften neu hrsg. u. eingel. v. Heinz Kimmerle, Heidelberg 2. Aufl. 1974.

[3] W. Dilthey, Die Entstehung der Hermeneutik, in: ders.: Philosophische Abhandlungen. Tübingen 1900, 185-202.

[4] G. Frank, St. Meier-Oeser, Hermeneutik, Methodenlehre, Exegese. Zur Theorie der Interpretation in der frühen Neuzeit, Stuttgart-Bad Cannstadt, 2011. 
[5] J. Schönert, F. Vollhardt, Geschichte der Hermeneutik und die Methodik der textinterpretierenden Disziplinen, Berlin, 2005.

[6] P. Szondi and T.Bahti. Introduction to Literary Hermeneutics Author. New Literary History, 1978, (10)1, pp. 17-29. 